\title{
Effect of Substituting Maize Based Stock-Feed Diets with Sorghum on the Performance of Quails
}

\author{
Lloyd Mbulwe, Mukachikwikwi Hamakoko, George Mhango, Mathew Moonga and Hezel Syankwede
}

\begin{abstract}
Sorghum has a high similarity to maize and therefore a good substitute for maize based diets in poultry stock-feed. Additionally, sorghum is processed just like maize in both dry and wet milling techniques. Nonetheless, a general misconception is that all sorghums have anti-quality factors (tannins). This misconception may have resulted in its underutilization in poultry feed in Zambia. However, various tannin free varieties and hybrids developed by the Sorghum \& Millets Improvement Programme are available in Zambia.

Kuyuma, a tannin free white sorghum variety was used to determine the suitability of using non-tannin white sorghum varieties in quail feed. In this study a maize-based stock-feed diet for quails was substituted with sorghum at four levels: $25 \%$, $50 \%, 75 \%$ and $100 \%$ in quail meat production. This was followed by measuring: (i) The weekly feed intake, (ii) The weekly gain in body weight and (iii) The weekly feed conversion ratio of quails.

The performance of quails fed on a maize-based diet was identical to quails fed on a sorghum-based diet at nearly all levels of substitution. The conversion ratios of maize and sorghum were also similar. Non-tannin white sorghums like Kuyuma can effectively substitute maize in quail diets. Utilizing sorghum in poultry diets could increase its social-economic value and help to reduce the cost of producing meat.
\end{abstract}

Index Terms - Sorghum, stock-feed, poultry, quails.

\section{INTRODUCTION}

Sorghum grain is utilized as food and feed in Zambia, but it is not readily available because very few values chains are developed for this crop. As a result, limited markets are available for small-scale farmers living mostly in remote rural areas. Sorghum remains largely a crop of small cultivators and is mostly consumed locally where it is grown [1]. Consumption constraints include few commercially available value-chains for flours, breads, breakfast cereals and other products such as stock-feeds. Fortunately, the urban marketplace is slowly changing as the food industry is beginning to develop and sell sorghum products [2]. Stockfeed production for fish and poultry (eggs and meats) have an enormous potential to help the growth of the sorghum industry and consequently improve the lives of thousands of sorghum farmers. There are several improved tannin-free white sorghum varieties developed by the Sorghum \& Millets Improvement Program (SMIP) at the Zambia Agriculture Research Institute (ZARI) suitable to develop the stock-feed industry immediately.

Stock-feed production from sorghum grain comes with

Published on October 13, 2020.

L. Mbulwe, Zambia Agriculture Research Institute, Zambia.

(e-mail: maclloydm.zari@gmail.com)

M. Hamakoko, Natural Resources Development College, Zambia.

(e-mail: info@nrdc.biz) several challenges. But the common misconception is that all sorghums have tannins, which are considered feed antiquality factors [3]. Luckily, many sorghum varieties and hybrids developed by SMIP do not contain condensed tannins. Others subjectively consider colored grain sorghums as having tannins, even so grain color is a poor indicator of tannin content. Grain color expressed in the pericarp is determined by genes that are independent of the genes that express condensed tannins [4]. Moreover, most of the improved white sorghum varieties used and preferred by farmers contain no tannins [5], [6].

Because sorghum grain with tannins decrease protein digestibility and feed efficiency in both humans and animals, stock-feed production from sorghum grain is mostly restricted to non-tannin types. On the other hand, tannins have antioxidant activities beneficial to human and animal health. Naturally, niche markets are evolving that produce food with high dietary fiber and antioxidants [7], [8]. High tannin sorghum grain can substitute only half of the maize-based diets unless chemical and/or physical processing methods are employed to lower the tannin content. This usually involves decomposing tannins by heating to $210{ }^{\circ} \mathrm{C}$.

Digestibility of sorghum carbohydrate is another consideration that possess challenges for the conversion of sorghum starch to energy. Nevertheless, there are many sorghum varieties that have been developed some of which have the same digestibility as maize. Poultry are reared specifically to produce meat in the shortest time possible. So, starch and protein digestibility measured using the feed conversion ratio are an important factor in poultry production systems. Nonetheless, there is a parallel move towards producing lean meats and so less digestible sorghum types will be essential for this parallel production system. Lean meats are thought to be higher quality meats and may fetch a premium price in future. The focus of this research was on non-tannin white sorghum grain to substitute maize in poultry diets.

Maize is the staple crop for many Zambians. It is used for human food and stock-feed production. Consumption of maize brings about competition for its use in human food and animal feed. Subsequently, this has a major impact on food security causing the prices of this commodity to go up and hence increasing the cost of the staple food for many Zambians. Naturally, this brings about government intervention in the pricing of maize. A gross margin analysis for sorghum in Lusitu area, Siavonga district, revealed that

G. Mhango, Natural Resources Development College, Zambia. M. Moonga, Natural Resources Development College, Zambia. H. Syankwede, Natural Resources Development College, Zambia. 
sorghum can be produced at half the input costs for maize [9][12]. The input costs can even be lower under small-holder farming conditions because some small-holder farmers rarely apply the relatively costly chemical fertilizers. Sorghum can significantly reduce the competition for maize and even allow for excess maize produced in the country to be exported and hence more foreign exchange can be earned from maize. This way sorghum can effectively contribute to the National Gross Domestic Product (NGDP).

The competitive advantage of sorghum is principally derived from its relative resilience. Sorghum is more suited to areas with marginal soils, high temperature and low rainfall than maize. Sorghum can grow and produce under conditions of drought, heat stress and unpredictable rainfall making it a hardier crop. The development and use of sorghum in the food and feed industry systems should be viewed as a contribution to national economic growth rather than competition with maize. Policies and investment strategies should be designed to exploit the competitive advantages of sorghum.

Research efforts by SMIP have resulted in the development of sorghums that are efficient at using fertilizer and water under extreme drought and heat stress conditions. This gives sorghum a competitive advantage and makes it suitable as a substitute crop with improved quality traits for food, feed, nutrition, and health [12]. This study is part of the efforts needed to promote sorghum in the food and feed industry and help to create markets for farmers and employment for youths. Incomes generated from sorghum will contribute to poverty alleviation in both urban and rural economies and overall, the national economy.

The total carbohydrate composition for maize and sorghum is nearly the same $(74.3 \%$ \& $74.6 \%$ respectively). Similarly, the fat and protein percentages are similar. Sorghum has most of the minerals elements in maize and has a nutrient composition comparable to that of maize. The available literature favors sorghum as a substitute for maize and vice versa [3], [13]-[16]. Therefore, maize based stock-feed diets for poultry can easily be replaced by low/non-tannin sorghums.

The general objective of this study was to evaluate the effect of substituting maize starch with sorghum starch in a poultry diet at four levels $(25 \%, 50 \%, 75 \%$ and $100 \%)$ and evaluate the performance of quails on these experimental diets. The specific objectives were to measure: (i) Weekly feed intake (FI) of quails, (ii) Weekly gain in body weight (BWG) of quails and (iii) Feed conversion ratio (FCR) of quails.

\section{MethodOlOGY}

100-day old unsexed chicks were bought from Ross Breeders Zambia Limited and feed on experimental diets at four levels of maize substitution with sorghum. The 100-day old chicks were split into five treatments consisting of 20 chicks. Treatment 1 (T1) were fed on $100 \%$ maize diet; this was the control treatment. Treatment 2 (T2) were fed on a $25 \%$ sorghum substituted maize diet, treatment 3 (T3) were fed on $50 \%$ sorghum substituted maize diet, treatment 4 (T4) were fed on $75 \%$ sorghum substituted maize diet, and treatment 5 (T5) were fed on $100 \%$ sorghum diet.
Sorghum grain was obtained from SMIP and maize grain was obtained from the Maize Improvement Program (MIP) at ZARI. Basic equipment used in the experiment are listed in appendix 1. A harmer mill was used to grind sorghum. The ground sorghum grain was similar in mean particle diameter $(0.7-0.9 \mathrm{~mm})$ and specific surface areas to maize processed for poultry diets. The starter diet (0-3 weeks) and finisher diet (46 weeks) were formulated using maize/sorghum, soybean, and soya oil to meet the nutrient requirements of commercial broilers [17]. The chemical composition of treatment 1 through 5, of the starter diet was the same, except for the amount of maize/sorghum which were varied according to the treatment, the same applied for the finisher diet. The chemical composition of the starter and fisher diets are tabulated in appendix 2 and 3, respectively.

The experimental design was a split-plot design with 20 replications, each chick was a replication. Each chick was randomly tagged from 1 to 100 and randomly assigned to the five treatment groups ( 5 diets). Chicks assigned to all the five groups were reared under standard production conditions for poultry (quails) throughout the study to reduced experimental errors. Data was analyzed using R-software version 4.0.2. [18].

\section{RESULTS}

Results from the study of the effect of substituting maizebased stock-feed diets with sorghum on the performance of quails are summarized in Tables 1,2 and 3 below. Significant differences were found for Feed Intake (FI) in week six between quails feed on $100 \%$ sorghum-based diets (treatment 5) and the rest of the treatments (treatments 1 to 4) (Table 1). There were no significant differences between treatments for Body Weight Gain (BWG) (Table 2) and Feed Conversion Ratio (FCR) (Table 3).

TABLE 1: DAILY FEED INTAKE (FI) OF QUAILS IN GRAMS (G) FED ON DIFFERENT SUBSTITUTION LEVELS OF MAIZE WITH SORGHUM, T1 TO T5

\begin{tabular}{ccccccc}
\hline Wk & T1 & T2 & T3 & T4 & T5 & P* $^{*}$ \\
\hline 3 & 12.6 & 10.7 & 10.2 & 11.0 & 10.1 & 0.7 \\
4 & 15.7 & 15.1 & 13.3 & 14.2 & 13.2 & 0.1 \\
5 & 18.2 & 18.2 & 16.4 & 15.9 & 15.2 & 0.1 \\
6 & $21.7^{\mathrm{a}}$ & $21.3^{\mathrm{ab}}$ & $20.2^{\mathrm{ab}}$ & $19.7^{\mathrm{a}}$ & $17.4^{\mathrm{c}}$ & 0.0 \\
\hline *P.Value $<0.05$ = Significant difference. Wk $=$ Week, T = Treatment.
\end{tabular}

TABLE 2: WEEKLY BODY WEIGHT GAIN (BWG) IN GRAMS (G) OF QUAILS FED ON DIFFERENT SUBSTITUTION LEVELS OF MAIZE WITH SORGHUM, T1 TO

\begin{tabular}{ccccccc}
\hline Wk & T1 & T2 & T3 & T4 & T5 & P* \\
\hline 3 & 43.7 & 36.1 & 28.4 & 38.5 & 33.6 & 0.1 \\
4 & 39.7 & 31.0 & 31.5 & 37.9 & 35.1 & 0.8 \\
5 & 35.8 & 34.9 & 42.6 & 32.1 & 34.2 & 0.9 \\
6 & 31.4 & 31.8 & 39.8 & 32.3 & 25.9 & 0.9 \\
\hline *P Value $<0.05=$ Significant difference. Wk $=$ Week, T = Treatment.
\end{tabular}

*P.Value $<0.05=$ Significant difference. $\mathrm{Wk}=\mathrm{Week}, \mathrm{T}=$ Treatment 
TABLE 3: WEEKLY FEED CONVERSION RATIO (FCR) OF QUAILS FED ON DIFFERENT SUBSTITUTION LEVELS OF MAIZE WITH SORGHUM, T1 TO T5

\begin{tabular}{ccccccc}
\hline Wk & T1 & T2 & T3 & T4 & T5 & P* \\
\hline 3 & 2.4 & 2.9 & 3.8 & 4.2 & 2.5 & 0.4 \\
4 & 5.2 & 3.3 & 4.0 & 3.3 & 3.0 & 0.7 \\
5 & 8.0 & 2.9 & 4.2 & 3.7 & 4.5 & 0.1 \\
6 & 4.5 & 3.1 & 3.9 & 3.3 & 5.2 & 0.6 \\
\hline
\end{tabular}

$*$ P.Value $<0.05=$ Significant difference. $\mathrm{Wk}=\mathrm{Week}, \mathrm{T}=$ Treatment

\section{DISCUSSION AND CONCLUSIONS}

The performance of quails on the maize-based stock feed Blood meal

The performance of quails on the maize-based stock-feed Poultry meal diet was comparable to the performance of quails on diets Limestone substituted with sorghum (Tables 1, 2, \& 3). Therefore, it $\begin{aligned} & \text { Lysine } \\ & \text { Methionine }\end{aligned}$ would be fair to assume that quails fed on stock-feed based Threonine on white maize will be similar in FI, BWG and FCR to quails Salt fed on tannin free white sorghum stock-feed.

For some unexplained reason, the quails lost some weight from week 3 to week 6 across the board regardless of the treatment except for treatment 3 (50\% sorghum substitution)
APPENDIX 2: CHEMICAL COMPOSITION OF THE STARTER DIET STOCK-FEED FOR QUAILS PER 100G OF FEED.

\begin{tabular}{lccccccc}
\hline Ingredient (g) & T1 & T2 & T3 & T4 & T 5 & Ingredient & ppm \\
\hline Maize & 53.00 & 39.75 & 26.5 & 13.25 & 0.00 & Crude protein & 24.9 \\
No. 3 meal & 0 & 0 & 0 & 0 & 0 & Crude fat & 3.5 \\
Soya ME & 40 & 40 & 40 & 40 & 40 & Crude fibre & 3.6 \\
Soya SE & 0 & 0 & 0 & 0 & 0 & Ash & 4.0 \\
Soya Full-fat & 0 & 0 & 0 & 0 & 0 & NDF & 10.6 \\
Wheat bran & 0 & 0 & 0 & 0 & 0 & Ca & 0.8 \\
Sunflower cake & 0 & 0 & 0 & 0 & 0 & Av P & 0.3 \\
Maize Bran & 0 & 0 & 0 & 0 & 0 & Ca/ Av. P & 2.6 \\
Rice bran & 0 & 0 & 0 & 0 & 0 & Mg & 0.2 \\
Cotton cake & 0 & 0 & 0 & 0 & 0 & Na & 0.1 \\
Sorghum & 0.00 & 13.25 & 26.5 & 39.75 & 53.00 & K & 1.1 \\
Meat\&Bonemeal & 0 & 0 & 0 & 0 & 0 & Cl & 0.1 \\
Fishmeal (LP) & 5 & 5 & 5 & 5 & 5 & dEB & 269.4 \\
Fishmeal (HP) & 0 & 0 & 0 & 0 & 0 & EW (Pigs) & 1.1 \\
Blood meal & 0 & 0 & 0 & 0 & 0 & ME poultry & 2922.7 \\
Poultry meal & 0 & 0 & 0 & 0 & 0 & dig. Lys & 1.3 \\
Limestone & 1.2 & 1.2 & 1.2 & 1.2 & 1.2 & dig. Meth & 0.5 \\
Lysine & 0.1 & 0.1 & 0.1 & 0.1 & 0.1 & dig. Cys & 0.3 \\
Methionine & 0.1 & 0.1 & 0.1 & 0.1 & 0.1 & dig.Meth.+Cyst & 0.8 \\
Threonine & 0 & 0 & 0 & 0 & 0 & dig. Threo & 0.8 \\
Salt & 0 & 0 & 0 & 0 & 0 & dig. Tryp & 0.3 \\
MCP & 0 & 0 & 0 & 0 & 0 & dig. Val & 1.0 \\
DCP & 0.3 & 0.3 & 0.3 & 0.3 & 0.3 & dig. Iso & 0.9 \\
\hline
\end{tabular}

$* \mathbf{T}=$ treatment, $\mathbf{p p m}=$ parts per million

APPENDIX 3: CHEMICAL COMPOSITION OF THE FINISHER DIET STOCK-FEED FOR QUAILS PER 100G OF FEED.

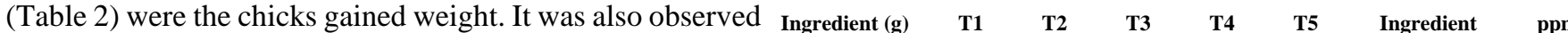

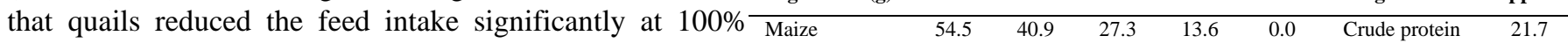
sorghum substitution in week 6. Even though this was No. 3 meal statistically significant, it was of no practical value since at Soya ME this stage the quails had reached culling stage (ready for the Soya Full-fat market) and it was not necessary to feed the birds beyond Wheat bran week 6. The reduced feed intake may have been due to Maize Bran Rice bran rancidity associated with feed storage in hot climates. $\quad$ Cotton cake

It was reasonable to concluded that non-tannin white Sorghum sorghum can effectively substitute maize in maize-based Fishmeal (LP) stock-feed diets partially or completely for quails and other Fishmeal (HP) poultry. Perhaps this might also be true for substituting maize Blood meal in stock-feed for aquaculture (fish farming). Since sorghum Limestone (g) can be grown at a cheaper price, it means that it is more cost effective to use sorghum in the production of stock-feed. However, additional studies are required before making further claims.

Limestone $(\mathrm{g})$
Lysine $(\mathrm{g})$
Methionine
Threonine
Salt $(\mathrm{g})$
$\mathrm{MCP}$
$\mathrm{DCP}(\mathrm{g})$

$* \mathrm{~T}=$ treatment, $\mathrm{ppm}=$ parts per million.

\section{APPENDIX}

\begin{tabular}{llc}
\multicolumn{2}{c}{ APPENDIX 1: BASIC EQUIPMENT AND MATERIALS USED IN THE STUDY } \\
\hline S/No. & Item description & Quantity \\
\hline 1. & Chick fount 4lt & 2.0 \\
2. & Chick feed tray-round & 2.0 \\
3. & Chick fount 10lt complete & 2.0 \\
4. & Feeder tubular -complete & 2.0 \\
5. & Nd Lasota s 200 d & 2.0 \\
6. & Gumboro i 200 d & 2.0 \\
7. & Virukill & 1.0 \\
8. & Stress pack (phenix) & 1.0 \\
9. & Amilyte 100g & 1.0 \\
10. & Lamp fitting only 4405477 & 1.0 \\
11. & Lamp infra red par red 4404901 175W & 1.0 \\
12. & Thermometer max/min TFA SB4303164 & 1.0 \\
13. & Chick fount 4lt & 2.0 \\
\hline
\end{tabular}

\section{ACKNOWLEDGMENT}

Dr. Mbulwe would like to recognize the efforts made by the Sorghum \& Millets Improvement Program, Maize Improvement Program and Natural Resources Development College for making this study possible. Special thanks go to Patson Syankwede, Prisca C. Syankwede, and Pr. Pemba M. Phiri.

\section{REFERENCES}

[1] G. Munkombwe, D. N'guni and A.M. Joaquim. "Strengthening the seed delivery system for enhanced adoption of improved sorghum varieties among smallholder farmers in Mozambique and Zambia”, presented at the sorghum conference in the $21^{\text {st }}$ Century. Cape Town South Africa, April 9-12, 2018.

[2] L. Mbulwe. "Identification of sorghum research sites for Zambia Breweries in collaboration with ZARI-SMIP: Field Report", presented at ZARI annual planning meeting, Chilanga, Zambia, May 9, 2018.

[3] J. Lindsay. "Sorghum: An ancient, healthy, and nutritious Old-World cereal". INTSORMIL Scientific Publications. 7. January 2010. https://digitalcommons.unl.edu/intsormilpubs/7. 
[4] D.H Hahn and L.W. Rooney. "Effect of genotype on tannins and phenols of sorghum", Cereal Chem, vol. 63, no. 1, pp. 4-8, 1986.

[5] J.M. Awika and L.W. Rooney. "Sorghum phytochemicals and their potential impact on human health". Phytochemistry vol. 65, pp. 11991221, May 2004.

[6] L. Mbulwe. "Strengthening the sorghum seed delivery system for enhanced production among smallholder farmers in Zambia", presented at ZARI annual planning meeting, Chilanga, Zambia, September 2018

[7] Y. Wu, X. Li, W. Xiang, C. Zhu, Z. Lin, Y. Wu, J. Li, S. Pandravada, D.D. Ridder, G. Bai and M.L. Wang. "Presence of tannins in sorghum grains is conditioned by different natural alleles of Tannin1", Proceedings of the National Academy of Sciences, vol. 109 no. 26 , pp.10281-10286, February 2012.

[8] N.A. Pugh, J.M. Awika, and W. L. Rooney. "Heritability of popping characteristics in sorghum grain", Crop Sci. vol. 57 pp. 71-77, January 2017.

[9] L. Mbulwe. "Addressing constraints in sorghum technology transfer", presented at a market linkage workshop (JICA-FoDiS), Siavonga, Zambia, September 14-15, 2011.

[10] M. Joseph. "Marketing margin analysis of the sorghum-based stock feed value chain in Zambia: empirical evidence from Lusitu, Chirundu district”. M.S. thesis, Dept. of Economics. Africa University, Harare, Zimbabwe, 2013.

[11] D. Lighton, P.M. Joseph, B. Joyce and T.M. Vincent. "Marketing proclivity, constraints, and opportunities in the sorghum-based stock feed value chain in Lusitu, Zambia", JAERD vol. 2, no. 3, pp. 110-122, February 2014

[12] L. Mbulwe. "Productivity trials end of season report (2019/2020 season): Sorghum \& Millets Improvement Programme (SMIP)", presented at ZARI annual planning meeting, Chilanga, Zambia, September 2020.

[13] V. Kumar, A.V. Elangovan and A.B. Mandal. "Utilization of reconstituted high-tannin sorghum in the diets of broiler chickens", Asian-australasian journal of animal sciences, vol. 18 no. 4, pp. 538544, April 2005.

[14] P.K. Tyagi, A.V. Elangovan, A.B. Mandal, P.K. Tyagi, S. Kaur and A.K Johri. "Effects of feeding low tannin sorghum grain to broiler chickens". Indian J. Anim. Nutr. vol. 20, no. 3, pp. 322-326, September 2003.

[15] P.G. Sannamani. "Feeding value of sorghum grains vis-à-vis yellow maize for broiler chicks". M.V.Sc. Thesis, Dept. Veterinary Science. Deemed University, IVRI, Izatnagar, India, 2002.

[16] S.S. Nagra, J.S. Chawla and P.S. Phaul. "Effect of feeding sorghum on growth performance of broilers". Indian J. Poult. Sci. vol. 25, pp.138144, 1990.

[17] A. Cecilia. "Broiler production in Zambia: Management, growth, diseases, and welfare". BSc. Thesis, Dept. of Animal Husbandry and Management, Swedish University of Agricultural Sciences. Uppsala, Sweden, 2014. http://stud.epsilon.slu.se

[18] W.N. Venables and D.M. Smith and the R Core Team. "An Introduction to R Notes on R: A Programming Environment for Data Analysis and Graphics Version 3.1.2", October 2014.

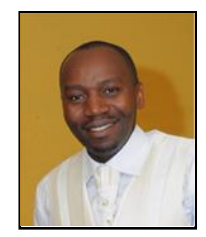

Lloyd Mbulwe was born in Mwinilunga, Zambia. He got his Ph.D. in Plant Breeding at Texas A\&M University, College Station, Texas, USA. Master of Science Degree in Plant Genetic Manipulation at the University of Nottingham, Nottingham, United Kingdom and a Bachelor of Agriculture Science Degree at the University of Zambia, Lusaka, Zambia. $\mathrm{He}$ is based at Golden Valley Research Trust, Zambia Agriculture Research Institute. He is a Principal Agriculture Research Officer directing the Sorghum and Millets Improvement Program. He is developing sorghum technologies that are contributing to socialeconomic development. He is currently working on developing improved varieties of sorghum for a wide range of uses from human food to animal feed and various industrial applications. $\mathrm{He}$ is also working on discovering better genetics for heat stress, low water use, low fertilizer inputs and low management. Special interests include addressing issues of climate and ecosystems adaptation for food security.

Over the years, he has managed to develop project proposals which brought significant amounts of money for various projects from the World Bank, African Development Bank, United Nations Environmental Program and Technical Centre for Agricultural and Rural Cooperation ACP-EU and many more to improve agriculture research, productivity and production in Zambia.
He is currently working on private public partnership projects with Anheuser-Busch International Beverages (ABInBev)/Zambia Breweries, Omega Foods, and other enterprises to develop new products from Sorghum. He has strong collaborative linkages on sorghum research with Texas A\&M University in USA and Sementes in Brazil. Additionally, he also assists in delivering special lectures in Plant Breeding and Genetics when called upon by various universities in Zambia and abroad. Further, he helps to supervise graduate and undergraduate students doing biological sciences, plant sciences and agricultural sciences at various universities.

Dr. Mbulwe is a member of the African Plant Breeding Association and is on the committee for Plant Variety Release at the Seed Control and Certification Institute (SCCI). He also assists the National Science and Technology Council (NSTC) to evaluate project proposals.

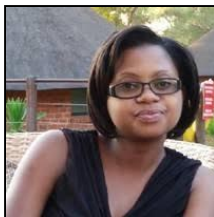

Mukachikwikwi Hamakoko was born in Kitwe, Zambia. She got her M.S. Degree in Epidemiology at the University of Zambia in Public Health in the School of Medicine. Her BSc. Degree in Veterinary Medicine was also obtained at the University of Zambia.

She is a veterinarian (veterinary doctor) by profession and is a lecturer at the Natural Resources Development College. She teaches Animal Sciences in her Department where she is currently a Senior Training Officer and acting as Head of Department. Her expertise includes animal husbandry, animal nutrition, animal behavior wildlife, toxicology, and public health

Dr. Hamakoko is an active member of the Veterinary Association of Zambia and a registered practitioner with the Veterinary Council of Zambia. 